Effect of antiarrhythmic drugs on small conductance calcium -activated potassium channels

Simo Vicens, Rafel; Sauter, Daniel Rafael Peter; Grunnet, Morten; Diness, Jonas Goldin; Bentzen, Bo Hjorth

Published in:

European Journal of Pharmacology

DOI:

10.1016/j.ejphar.2017.03.039

Publication date:

2017

Document version

Peer reviewed version

Citation for published version (APA):

Simo Vicens, R., Sauter, D. R. P., Grunnet, M., Diness, J. G., \& Bentzen, B. H. (2017). Effect of antiarrhythmic drugs on small conductance calcium -activated potassium channels. European Journal of Pharmacology, 803, 118-123. https://doi.org/10.1016/j.ejphar.2017.03.039 


\section{Effect of antiarrhythmic drugs on small conductance calcium - activated potassium channels}

Rafel Simó Vicens ${ }^{a, b}$, Daniel R.P. Sauter ${ }^{a, b}$, Morten Grunnet ${ }^{b}$, Jonas G. Diness ${ }^{b}$, Bo H. Bentzen ${ }^{a, b}$

${ }^{a}$ Biomedical Institute, University of Copenhagen, Blegdamsvej 3B, DK-2200, Copenhagen,

Denmark

${ }^{b}$ Acesion Pharma, Ole Maaløes Vej 3, DK-2200, Copenhagen, Denmark.

Corresponding author: Bo H. Bentzen, bobe@sund.ku.dk, Blegdamsvej 3B, DK-2200,

Copenhagen, Denmark 


\section{Abstract}

Atrial fibrillation (AF) is the most common type of arrhythmia. Current pharmacological treatment for $\mathrm{AF}$ is moderately effective and/or increases the risk of serious ventricular adverse effects. To avoid ventricular adverse effects, a new target has been considered, the small conductance calcium-activated $\mathrm{K}^{+}$channels $\left(\mathrm{K}_{\mathrm{Ca}} 2 . \mathrm{X}, \mathrm{SK}\right.$ channels). In the heart, $\mathrm{K}_{\mathrm{Ca}} 2 . \mathrm{X}$ channels are functionally more important in atria compared to ventricles, and pharmacological inhibition of the channel confers atrial selective prolongation of the cardiac action potential and converts AF to sinus rhythm in animal models of AF. Whether antiarrhythmic drugs (AADs) recommended for treating $\mathrm{AF}$ target $\mathrm{K}_{\mathrm{Ca}} 2 . \mathrm{X}$ channels is unknown. To this end, we tested a large number of AADs on the human $\mathrm{K}_{\mathrm{Ca}} 2.2$ and $\mathrm{K}_{\mathrm{Ca}} 2.3$ channels to assess their effect on this new target using automated whole-cell patch clamp. Of the AADs recommended for treatment of AF only dofetilide and propafenone inhibited $\mathrm{hK}_{\mathrm{Ca}} 2 . \mathrm{X}$ channels, with no subtype selectivity. The calculated IC 50 were $90 \pm 10 \mu \mathrm{mol} / \mathrm{I}$ vs $60 \pm 10 \mu \mathrm{mol} / \mathrm{I}$ for dofetilide and $42 \pm 4 \mu \mathrm{mol} / \mathrm{I}$ vs $80 \pm 20 \mu \mathrm{mol} / \mathrm{I}$ for propafenone (hK $\left.\mathrm{Ca}_{\mathrm{Ca}} 2.3 \mathrm{vs} \mathrm{hK}_{\mathrm{Ca}} 2.2\right)$. Whether this inhibition has clinical importance for their antiarrhythmic effect is unlikely, as the calculated $I C_{50}$ values are very high compared to the effective free therapeutic plasma concentration of the drugs when used for AF treatment, $40,000-$ fold for dofetilide and 140-fold higher for propafenone.

Key words: atrial fibrillation; $\mathrm{K}_{\mathrm{Ca}} 2$ channel; calcium-activated potassium channel; antiarrhythmic drug; automated patch clamp. 


\section{Chemical compounds studied in this article}

Amiodarone hydrochloride (PubChem CID: 441325), disopyramide (PubChem CID:

3114), dofetilide (PubChem CID: 71329), dronedarone (PubChem CID: 208898),

flecainide (PubChem CID: 3356), ibutilide (PubChem CID: 60753), quinidine (PubChem

CID: 441074), propafenone (PubChem CID: 4932), sotalol (PubChem CID: 5253) and vernakalant hydrochloride (PubChem CID: 9930048). 


\section{Introduction}

AF has become one of the most important public health problems in developed countries. The total lifetime risks for development of AF are 1 in 4 for 40 years age people and older (Lloyd-Jones et al., 2004). Furthermore, it is expected that by 2030, only in Europe, a total of 14 - 17 million people will have AF and 120,000 - 215,000 new cases will appear every year (Zoni-Berisso et al., 2014). Therefore, it is important to have effective and safe therapeutic strategies to treat patients with AF.

Over the past years, a number of drugs have been developed for rhythm control therapy and treatment of AF (Waks and Zimetbaum, 2016). Unfortunately, these drugs are only moderately effective, have many adverse effects and/or may trigger ventricular arrhythmias. Even recently approved drugs, like vernakalant, have limited effects on the treatment of AF and efficacy of the compound is drastically reduced after just a few days of consistent atrial fibrillation (Tsuji and Dobrev, 2013). Therefore, it is important to find new atrial selective targets for AF treatment.

One promising new target is the small conductance calcium-activated potassium channel ( $\mathrm{K}_{\mathrm{Ca}} 2 . \mathrm{X}$ or SK channel). This ion channel plays an important role on the late repolarization phase of especially atrial cardiomyocytes and its inhibition results in the prolongation of the effective refractory period (Diness et al., 2010), a strategy that has been used for the development of class III antiarrhythmic drugs (Schmitt et al., 2014). Moreover, this protein is functionally more important in atria when compared to ventricles (Xu et al., 2003), which could help avoid possible ventricular adverse effects. It has also been demonstrated that pharmacological inhibition of the $\mathrm{K}_{\mathrm{Ca}} 2 . \mathrm{X}$ channel confers atrial selective prolongation of cardiac action potential and converts AF to 
sinus rhythm in a number of small and large animal models (Haugaard et al., 2015; Qi et al., 2014; Skibsbye et al., 2011).

Whether antiarrhythmic drugs (AAD) recommended for treating AF target $\mathrm{K}_{\mathrm{Ca}} 2 . \mathrm{X}$ channels is unknown. To this end, we tested a large number of AADs (Table 1) on the human $\mathrm{K}_{\mathrm{Ca}} 2 . \mathrm{X}$ channels to assess their effect on this new target and its clinical significance.

\section{Materials and methods}

\subsection{Cell culture}

Two different stable HEK293 cell lines expressing one specific subtype of the human $\mathrm{K}_{\mathrm{Ca}} 2$ channel, either $\mathrm{K}_{\mathrm{Ca}} 2.2$ or $\mathrm{K}_{\mathrm{Ca}} 2.3$, obtained from NeuroSearch $\mathrm{A} / \mathrm{S}$ (Ballerup, Denmark) (Strøbæk et al., 2004), were used to conduct the experiments. The cells were cultured in Dulbecco's modified Eagle's medium (DMEM1965, ThermoFisher, USA) supplemented with $2.2 \mathrm{~g} / \mathrm{I} \mathrm{NaHCO} 3,5.96 \mathrm{~g} / \mathrm{l}$ HEPES, $10 \mathrm{ml} / \mathrm{I}$ Glutamax (Gibco, USA), $10 \%$ foetal bovine serum (Biowest, France), $100 \mathrm{U} / \mathrm{ml}$ of penicillin/streptomycin (Sigma, Germany) and $100 \mu \mathrm{g} / \mathrm{ml}$ geneticin (Gibco, USA) in T175 flasks. On the day of the experiment, when cells were $80-90 \%$ confluent, $1 \mathrm{ml}$ of Detachin ${ }^{\mathrm{TM}}$ (Amsbio, United Kingdom) was used to detach the cells after being washed with free calcium and magnesium phosphate-buffered saline. Then, the cells were resuspended in $5 \mathrm{ml}$ of serum-free DMEM media containing $0.04 \mathrm{mg} / \mathrm{ml}$ soy bean trypsin inhibitor (Sigma, Germany) and 25 mmol/I HEPES buffer (Sigma, Germany).

\subsection{Solutions and drugs}


Whole cell patch-clamp experiments were conducted using symmetrical $\mathrm{K}^{+}$solutions. The extracellular solution contained $0.1 \mathrm{mmol} / \mathrm{l} \mathrm{CaCl} 2,3 \mathrm{mmol} / \mathrm{I} \mathrm{MgCl}, 150 \mathrm{mmol} / \mathrm{l} \mathrm{KCl}$, $10 \mathrm{mmol} / \mathrm{I} \mathrm{HEPES}$ and $10 \mathrm{mmol} / \mathrm{l}$ glucose $(\mathrm{pH}=7.4$ and 285-295 $\mathrm{mOsm})$ and the intracellular solution contained $8.106 \mathrm{mmol} / \mathrm{l} \mathrm{CaCl} 2,1.167 \mathrm{mmol} / \mathrm{l} \mathrm{MgCl} 2,10 \mathrm{mmol} / \mathrm{l}$ EGTA, $150 \mathrm{mmol} / \mathrm{I} \mathrm{KCl}, 10 \mathrm{mmol} / \mathrm{I} \mathrm{HEPES}, 31.25 / 10 \mathrm{mmol} / \mathrm{I} \mathrm{KOH} / \mathrm{EGTA}$ and $15 \mathrm{mmol} / \mathrm{I}$ $\mathrm{KOH}(\mathrm{pH}=7.2)$. Final free $\mathrm{Ca}^{2+}$ concentration was calculated to $400 \mathrm{nmol} / \mathrm{l}$ as previously described (Strobaek et al., 2006). The osmolarity of the intracellular solution was adjusted using sucrose (Sigma, Germany) to match the extracellular solution.

Bicuculline methiodide, propafenone, quinidine, sotalol, flecainide, dofetilide, dronedarone, disopyramide and ibutilide were purchased from Sigma (Germany) and amiodarone hydrochloride was purchased from Tocris (United Kingdom) in their solid forms. The drugs were solubilized in pure dimethyl sulfoxide (Sigma, Germany) at a stock concentration of $10 \mathrm{mmol} / \mathrm{l}$ and stored at $-20^{\circ} \mathrm{C}$. On the day of the experiment, aliquots were diluted to the desired concentration in the extracellular solution. Vernakalant was purchased as the pharmaceutical preparation Brinavess $20 \mathrm{mg} / \mathrm{ml}$ (Cardiome, United Kingdom) and diluted at the day of the experiment to the desired concentrations in the extracellular solution to conduct the experiments with vernakalant hydrochloride.

\subsection{Electrophysiology}

Whole-cell experiments were conducted using the automated patch-clamp platform QPatch 16 (Sophion, Denmark). After breaking into the cell and establishing a giga seal, a first application of extracellular solution (saline) was applied. This application was followed by the $\mathrm{K}_{\mathrm{Ca}} 2 . \mathrm{X}$ inhibitor bicuculline $(100 \mu \mathrm{mol} / \mathrm{l})$, used as positive control for 
functional channel expression. Bicuculline was washed off with two more saline applications before applying the test drug. The last saline application prior to the test drug was used as baseline. After this, the test drug was applied at six increasing concentrations at a time scale that allowed for a potential steady-state in current reduction. Finally, after washing twice with saline, the experiment ended with application of bicuculline $(100 \mu \mathrm{mol} / \mathrm{I})$. The different steps of the protocol are illustrated in Fig. 1. Currents were elicited using 200 ms voltage ramps ranging from $80 \mathrm{mV}$ to $+80 \mathrm{mV}$ from a holding potential of $0 \mathrm{mV}$ and were applied every $2 \mathrm{~s}$ with a sample rate of $10 \mathrm{kHz}$. To avoid background noise, the recorded signals were filtered using a Bessel filter with a cut-off frequency of $3 \mathrm{kHz}$. Series resistance compensation was set at $80 \%$.

\subsection{Data analysis and statistics}

Current amplitudes were measured at $-80 \mathrm{mV}$, and the mean of the last three recordings during each application was used for further analysis. To calculate changes in relative current, the mean values were normalized using the last saline application prior to applying test compound as baseline and the first bicuculline injection as reference for total inhibition of the channel. The data were then plotted and fitted using the following equation on GraphPad Prism 7: $Y=Y_{\min }+\left(Y_{\min }+Y_{\max }\right) /\left(1+10^{\mathrm{X}-\log / C 50}\right)$, where $\mathrm{Y}$ is the normalized measured current, $\mathrm{X}$ is the logarithm of the dose of the tested drug and $\mathrm{IC}_{50}$ the drug concentration needed to inhibit $50 \%$ of the current. In all cases a Hill slope of -1.0 was presumed. Individual $I C_{50}$ values were calculated for each experiment and then used to obtain the final mean \pm S.E.M. 
Correction for baseline drift was applied if applicable, using the QPatch software and the bicuculline applications at the beginning and the end of the experiment as references.

Student's t-tests were used to determine subtype selectivity of test drugs.

\section{Results}

3.1. Amiodarone, disopyramide, dronedarone, flecainide, ibutilide, quinidine, sotalol and vernakalant have no effect on the $h K_{c a} 2.3$ channel.

Currents were recorded from HEK cells stably expressing $\mathrm{hK}_{\mathrm{Ca}_{2}} 2.3$ using an automated patch clamp system. In symmetrical intra- and extracellular $\mathrm{K}^{+}$concentrations, $\mathrm{hK}_{\mathrm{Ca}} 2.3$ currents displayed a characteristic inwardly rectifying current-voltage relationship and were inhibited by bicuculline (Fig. 1). A first screening of the AADs was conducted on the $h K_{\mathrm{Ca}} 2.3$ channel. For each drug we tested six different concentrations, starting at $0.1 \mu \mathrm{mol} / \mathrm{l}$ and finishing at $30 \mu \mathrm{mol} / \mathrm{I}$. In the case of amiodarone the used concentrations were between $0.3 \mu \mathrm{mol} / \mathrm{l}$ and $100 \mu \mathrm{mol} / \mathrm{l}$ (Fig. 2).

Amiodarone $(n=6)$, disopyramide $(n=8)$, dronedarone $(n=5)$, flecainide $(n=6)$, ibutilide $(n=5)$, quinidine $(n=5)$, sotalol $(n=5)$ and vernakalant $(n=5)$ had no effect on the $\mathrm{hK}_{\mathrm{Ca}} 2.3$ current (Fig. 2). Only dofetilide and propafenone showed concentration-dependent inhibition at the highest concentrations on the $\mathrm{hK}_{\mathrm{Ca}} 2.3$ and therefore were selected for further investigation.

\subsection{Dofetilide and propafenone are weak inhibitors of both $h K_{C a} 2.3$ and $h K_{C a} 2.2$ with} no subtype selectivity. 
In order to obtain a complete inhibition curve for dofetilide and propafenone, a second round of experiments was conducted using higher concentrations, starting at $1 \mu \mathrm{mol} / \mathrm{I}$ and finishing at $300 \mu \mathrm{mol} / \mathrm{l}$ (Fig. 3).

As can be seen in Fig. 3A and Fig. 3B, dofetilide and propafenone inhibited the $\mathrm{hK}_{\mathrm{Ca}} 2.3$ current in a dose dependent manner. The effect started at $10 \mu \mathrm{mol} / \mathrm{I}$ for both drugs and reached nearly complete inhibition at $300 \mu \mathrm{mol} / \mathrm{I}$. In the case of propafenone, a pronounced drift of the current was observed at the beginning of each new dose application, even after baseline correction. This drift, which was specific for propafenone, stabilized at the end of each application and it was less pronounced as the concentration of the drug was increased. The calculated $I C_{50}$ for dofetilide and propafenone were $90 \pm 10 \mu \mathrm{mol} / \mathrm{I}(\mathrm{n}=13)$ and $42 \pm 4 \mu \mathrm{mol} / \mathrm{l}(\mathrm{n}=8)$ for $\mathrm{hK}_{\mathrm{Ca}} 2.3$, respectively (Fig. 4). To address if dofetilide or propafenone displayed subtype selective effects, we also tested both drugs on HEK cells stably expressing the $\mathrm{hK}_{\mathrm{Ca}} 2.2$ channel. Dofetilide and propafenone were applied on the $\mathrm{hK}_{\mathrm{Ca}} 2.2$ expressing cells at the same concentrations and using the same protocol as described for $\mathrm{hK}_{\mathrm{Ca}} 2.3$ channel. Both drugs were also able to inhibit $\mathrm{hK}_{\mathrm{Ca}} 2.2$ currents in a concentration dependent manner (data not shown). In this case, the effect of dofetilide started at a lower dose of $3 \mu \mathrm{mol} / \mathrm{l}$. Inhibition by propafenone was first observed at $10 \mu \mathrm{mol} / \mathrm{l}$, as seen in $h K_{\mathrm{Ca}^{2}}$ 2.3. On the $h \mathrm{~K}_{\mathrm{Ca}} 2.2$ channel the characteristic drift of propafenone was also present at the beginning of every dose application and it stabilized as the dose of the drug was increased. The calculated $\mathrm{IC}_{50}$ for dofetilide and propafenone on the $\mathrm{hK}_{\mathrm{Ca}} 2.2$ channel were $60 \pm 10 \mu \mathrm{mol} / \mathrm{I}(\mathrm{n}=13)$ and $80 \pm 20 \mu \mathrm{mol} / \mathrm{I}(\mathrm{n}=6)$, respectively. Neither dofetilide $(p=0.1915)$ nor propafenone $(p=0.1816)$ showed any subtype selectivity. Due to the apparent weak binding and fast $k_{\text {on }}$ and $k_{\text {off }}$ of dofetilide and propafenone 
(Fig. 4), only current measurements corresponding to steady states, were considered to calculate the $\mathrm{IC}_{50}$.

\section{Discussion}

Despite being the most common type of arrhythmia, safe and effective AF treatment continues to be an unmet medical need. It is therefore important to find new strategies and targets to treat this increasingly prevalent disease. It has been revealed that both chronic (Voigt et al., 2012) and paroxysmal AF (Voigt et al., 2014) are associated with abnormal $\mathrm{Ca}^{2+}{ }_{-}$handling, like spontaneous sarcoplasmic reticulum $\mathrm{Ca}^{2+}{ }_{-}$ release and delayed after depolarizations. These events may modulate and activate other ion channels, such as KCa2.x, resulting in shorter APDs and increased AF vulnerability. Therefore, the $\mathrm{K}_{\mathrm{Ca}} 2 . \mathrm{X}$ channel is a promising new atrial selective target whose inhibition has proven to be efficacious in both cardioversion and prevention of new AF episodes in a number of animal models (Goldin Diness et al., 2011; Haugaard et al., 2015; Qi et al., 2014; Skibsbye et al., 2011). The identification and development of novel drugs targeting the cardiac $\mathrm{K}_{\mathrm{Ca}} 2 . \mathrm{X}$ channels and the understanding of their role in cardiac function may end up in a whole new AF therapy. AADs recommended for treating AF target a number of ion channels and receptors, but whether they can inhibit $\mathrm{K}_{\mathrm{Ca}} 2 . \mathrm{X}$ channels has not been systematically tested until now. Amiodarone has previously been reported to inhibit $\mathrm{K}_{\mathrm{Ca}} 2.2$ channels expressed in HEK-293 cells (Turker et al., 2013), but this study is the first to test a large number of the recommended AADs for treatment of $A F$ on the $h K_{C_{a}} 2$ channel. Ten AADs at six different concentrations ranging between $0.1-30 \mu \mathrm{mol} / \mathrm{I}$ on the $\mathrm{hK}_{\mathrm{Ca}} 2.3$ channel were tested. 
From this first screening, only dofetilide and propafenone showed concentrationdependent inhibition of the $\mathrm{hK}_{\mathrm{Ca}} 2.3$ current. Amiodarone, disopyramide, dronedarone, flecainide, ibutilide, quinidine, sotalol and vernakalant had no effect on the $\mathrm{hK}_{\mathrm{Ca}} 2.3$ current at any of the tested concentrations. The study published by Turker et al (2013) characterized the effect of amiodarone on the $\mathrm{hK}_{\mathrm{Ca}} 2.2$ channel and showed that amiodarone was able to inhibit the $I_{\mathrm{KCa}}$ current with an $\mathrm{IC}_{50}$ of $3 \mu \mathrm{mol} / \mathrm{I}$ when intracellular free $\mathrm{Ca}^{2+}$ concentration was $1 \mu \mathrm{mol} / \mathrm{I}$. Our experiments failed to show any effect of amiodarone at any of the tested concentrations on any of the $\mathrm{K}_{\mathrm{Ca}} 2$ subtypes (data not shown for $\mathrm{hK}_{\mathrm{Ca}} 2.2$ ). This contradiction might be explained by the strong calcium dependent effect of amiodarone on the $\mathrm{hK}_{\mathrm{Ca}} 2$ channel, which was also reported in Turker's work. According to the mentioned study, $30 \mu \mathrm{mol} / \mathrm{l}$ amiodarone were able to inhibit around $80 \%$ of the $I_{\mathrm{KCa}}$ when the intracellular $\mathrm{Ca}^{2+}$ concentration was $1 \mu \mathrm{mol} / \mathrm{l}$, but the effect dropped drastically when $\mathrm{Ca}^{2+}$ concentration was decreased. As they state in the discussion of their work, it is possible that $400 \mathrm{nmol} / \mathrm{l}$ of intracellular $\mathrm{Ca}^{2+}$ concentration (Desk and Williams, 1994), the one chosen for our screening, is not enough to assess the inhibitory effect of amiodarone at $10 \mu \mathrm{mol} / \mathrm{l}$, although we were not able to see any significant effect at higher concentrations neither. Another important difference between Turker's work and the present study are the $\mathrm{K}^{+}$concentrations used for the extracellular and intracellular solutions. While Turker used physiological $\mathrm{K}^{+}$concentrations for their experiments, in this study, we used symmetrical $\mathrm{K}^{+}$solutions. In any case, it is improbable that the antiarrhythmic effect of amiodarone is partly due to its $\mathrm{hK}_{\mathrm{Ca}} 2$ inhibition because, in a clinical situation, the effective free therapeutic plasma concentration of amiodarone for AF treatment is below $1 \mathrm{nmol} / \mathrm{I}$ (see Table 1), 3,000 times lower than the previously reported IC $\mathrm{C}_{50}$. 
The second round of experiments included dofetilide and propafenone. The selected AADs were tested at a higher concentration range $(1-300 \mu \mathrm{mol} / \mathrm{l})$ in order to obtain complete inhibition curves. Moreover, the same experiments were conducted on both $\mathrm{hK}_{\mathrm{Ca}} 2.3$ and $\mathrm{hK} \mathrm{Ca}_{\mathrm{C}} 2.2$ to assess possible subtype selectivity. The calculated $\mathrm{IC}_{50}$ for dofetilide and propafenone were $60 \pm 10 \mu \mathrm{mol} / \mathrm{l}$ and $80 \pm 20 \mu \mathrm{mol} / \mathrm{I}$ for $\mathrm{hK}_{\mathrm{Ca}} 2.2$, and 90 $\pm 10 \mu \mathrm{mol} / \mathrm{l}$ and $42 \pm 4 \mu \mathrm{mol} / \mathrm{l}$ for $\mathrm{hK}_{\mathrm{Ca}} 2.3$, respectively. Neither dofetilide nor propafenone showed any subtype selectivity. In the case of propafenone, a rapid "run up" of current was observed shortly after the application of the drug in all the performed experiments. This run up stabilizes with time and is less pronounced when the concentration of propafenone is increased. It could be speculated that this phenomenon might be explained by an extremely fast $k_{\text {on }}$ and $k_{\text {off }}$ of propafenone on the $\mathrm{hK}_{\mathrm{Ca}} 2$ channel. The fast binding of propafenone on the channel is followed by the also rapid unbinding of the drug, which is depicted as a current run up on the currenttime plots, until equilibrium is reached and the current stabilized. The higher the concentration, the faster the equilibrium was reached, reducing the run up of the current. For this reason, only the measurements corresponding to the steady state were considered in order to calculate the $\mathrm{IC}_{50}$.

Although dofetilide and propafenone were able to inhibit both $\mathrm{hK}_{\mathrm{Ca}} 2.2$ and $\mathrm{hK}_{\mathrm{Ca}} 2.3$ currents, it is highly improbable that this effect has any importance for their antiarrhythmic effects observed in the clinic. The calculated $I C_{50}$ for both drugs are extremely high when compared to the highest effective therapeutic free plasma concentration used for AF treatment (see Table 1), 40,000-fold and 140-fold higher for dofetilide and propafenone, respectively. 


\section{Conclusions}

Ten of the most common AADs used for the treatment of AF have been screened to assess their effect on the $\mathrm{hK}_{\mathrm{Ca}} 2$ channel using whole-cell automated patch-clamp. Only two of them, dofetilide and propafenone, were able to weakly inhibit both $\mathrm{hK}_{\mathrm{Ca}} 2.2$ and $\mathrm{hK}_{\mathrm{Ca}} 2.3$ in a concentration-dependent fashion with no subtype selectivity. Since the $\mathrm{IC}_{50}$ of the drugs on the $\mathrm{hK}_{\mathrm{Ca}} 2$ channel is very high when compared to their effective therapeutic free plasma concentration, it is unlikely that this inhibition has any clinical relevance for their antiarrhythmic effect. More efforts on the development of new effective and safe drugs selectively targeting the $\mathrm{K}_{\mathrm{Ca}} 2 . \mathrm{X}$ channels should be considered to improve AF treatment.

\subsection{Limitations of the study}

Manual patch clamp is the gold standard for electrophysiology. However automated patch clamp allows for higher throughput. This technique is successfully and continuously being used for primary and secondary drug screening on a great range of ion channels, including calcium-activated potassium channel (Coleman et al., 2014). Moreover, experiments on automated patch clamp systems are highly reproducible and comparable to the results obtained by the manual patch clamp technique (Korsgaard et al., 2009).

Funding: This work was supported by the European Union's Horizon 2020 research and innovation programme under the Marie Sklodowska-Curie grant agreement No. 675351 and the Innovation Fund Denmark. 


\section{References}

Coleman, N., Brown, B.M., Oliván-Viguera, A., Singh, V., Olmstead, M.M., Valero, M.S., Köhler, R., Wulff, H., 2014. New Positive Ca2+ -Activated K+ Channel Gating Modulators with Selectivity for KCa3.1. Mol. Pharmacol. 86, 342-357. doi:10.1165/rcmb.2006-03580C

Desk, R., Williams, L., 1994. A Dynamic Model of the Cardiac Ventricular Action Potential Simulations of Ionic Currents and Concentration Changes. Circ Res 1071-1096.

Diness, J.G., Sørensen, U.S., Nissen, J.D., Al-Shahib, B., Jespersen, T., Grunnet, M., Hansen, R.S., 2010. Inhibition of small-conductance ca2+-activated k+ channels terminates and protects against atrial fibrillation. Circ. Arrhythmia Electrophysiol. 3, 380-390. doi:10.1161/CIRCEP.110.957407

Goldin Diness, J., Skibsbye, L., Jespersen, T., Bartels, E.D., Sørensen, U.S., Hansen, R.S., Grunnet, M., 2011. Effects on atrial fibrillation in aged hypertensive rats by Ca2+activated $\mathrm{K}+$ channel inhibition. Hypertension. doi:10.1161/HYPERTENSIONAHA.111.170613

Haugaard, M.M., Hesselkilde, E.Z., Pehrson, S., Carstensen, H., Flethøj, M., Præstegaard, K.F., Sørensen, U.S., Diness, J.G., Grunnet, M., Buhl, R., Jespersen, T., 2015. Pharmacologic inhibition of small-conductance calcium-activated potassium (SK) channels by NS8593 reveals atrial antiarrhythmic potential in horses. Hear. Rhythm 12, 825-835. doi:10.1016/j.hrthm.2014.12.028

Korsgaard, M.P.G., Strøbaek, D., Christophersen, P., 2009. Automated planar electrode 
electrophysiology in drug discovery: examples of the use of QPatch in basic characterization and high content screening on $\mathrm{Na}(\mathrm{v}), \mathrm{K}(\mathrm{Ca}) 2.3$, and $\mathrm{K}(\mathrm{v}) 11.1$ channels. Comb. Chem. High Throughput Screen. 12, 51-63. doi:10.2174/138620709787048037

Lloyd-Jones, D.M., Wang, T.J., Leip, E.P., Larson, M.G., Levy, D., Vasan, R.S., D’Agostino, R.B., Massaro, J.M., Beiser, A., Wolf, P.A., Benjamin, E.J., 2004. Lifetime risk for development of atrial fibrillation: The framingham heart study. Circulation 110, 1042-1046. doi:10.1161/01.CIR.0000140263.20897.42

Qi, X.Y., Diness, J.G., Brundel, B.J.J.M., Zhou, X.B., Naud, P., Wu, C.T., Huang, H., Harada, M., Aflaki, M., Dobrev, D., Grunnet, M., Nattel, S., 2014. Role of smallconductance calcium-activated potassium channels in atrial electrophysiology and fibrillation in the dog. Circulation 129, 430-440.

doi:10.1161/CIRCULATIONAHA.113.003019

Schmitt, N., Grunnet, M., Olesen, S.-P., 2014. Cardiac potassium channel subtypes: new roles in repolarization and arrhythmia. Physiol. Rev. 94, 609-53. doi:10.1152/physrev.00022.2013

Skibsbye, L., Diness, J.G., Sørensen, U.S., Hansen, R.S., Grunnet, M., 2011. The duration of pacing-induced atrial fibrillation is reduced in vivo by inhibition of small conductance $\mathrm{Ca}(2+)$-activated K(+) channels. J. Cardiovasc. Pharmacol. 57, 672681. doi:10.1097/FJC.0b013e318217943d

Strobaek, D., Hougaard, C., Johansen, T.H., Sorensen, U.S., Nielsen, E.O., Nielsen, K.S., Taylor, R.D., Pedarzani, P., Christophersen, P., 2006. Inhibitory gating modulation of small conductance Ca2+-activated $\mathrm{K}+$ channels by the synthetic compound (R)- 
$\mathrm{N}$-(benzimidazol-2-yl)-1,2,3,4-tetrahydro-1-naphtylamine (NS8593) reduces afterhyperpolarizing current in hippocampal CA1 neurons. Mol. Pharmacol. 70, 1771-1782. doi:10.1124/mol.106.027110.small

Strøbæk, D., Teuber, L., Jørgensen, T.D., Ahring, P.K., Kjær, K., Hansen, R.S., Olesen, S.P., Christophersen, P., Skaaning-Jensen, B., 2004. Activation of human IK and SK Ca 2+-activated K + channels by NS309 (6,7-dichloro-1H-indole-2,3-dione 3oxime). Biochim. Biophys. Acta - Biomembr. 1665, 1-5. doi:10.1016/j.bbamem.2004.07.006

Tsuji, Y., Dobrev, D., 2013. Safety and efficacy of vernakalant for acute cardioversion of atrial fibrillation: an update. Vasc. Health Risk Manag. 9, 165-175. doi:10.2147/VHRM.S43720

Turker, I., Yu, C.C., Chang, P.C., Chen, Z., Sohma, Y., Lin, S.F., Chen, P.S., Ai, T., 2013. Amiodarone Inhibits Apamin-Sensitive Potassium Currents. PLoS One 8. doi:10.1371/journal.pone.0070450

Voigt, N., Heijman, J., Wang, Q., Chiang, D.Y., Li, N., Karck, M., Wehrens, X.H.T., Nattel, S., Dobrev, D., 2014. Cellular and molecular mechanisms of atrial arrhythmogenesis in patients with paroxysmal atrial fibrillation. Circulation 129, 145-156. doi:10.1161/CIRCULATIONAHA.113.006641

Voigt, N., Li, N., Wang, Q., Wang, W., Trafford, A.W., Abu-Taha, I., Sun, Q., Wieland, T., Ravens, U., Nattel, S., Wehrens, X.H.T., Dobrev, D., 2012. Enhanced sarcoplasmic reticulum $\mathrm{Ca} 2+$ Leak and increased $\mathrm{Na}+-\mathrm{Ca} 2+$ exchanger function underlie delayed afterdepolarizations in patients with chronic atrial fibrillation. Circulation 125, 2059-2070. doi:10.1161/CIRCULATIONAHA.111.067306 
Waks, J.W., Zimetbaum, P., 2016. Antiarrhythmic Drug Therapy for Rhythm Control in Atrial Fibrillation. J. Cardiovasc. Pharmacol. Ther. doi:10.1177/1074248416651722

Xu, Y., Tuteja, D., Zhang, Z., Xu, D., Zhang, Y., Rodriguez, J., Nie, L., Tuxson, H.R., Young, J.N., Glatter, K.A., V??zquez, A.E., Yamoah, E.N., Chiamvimonvat, N., 2003. Molecular identification and functional roles of a $\mathrm{Ca}(2+)$-activated $\mathrm{K}+$ channel in human and mouse hearts. J. Biol. Chem. 278, 49085-49094. doi:10.1074/jbc.M307508200

Zoni-Berisso, M., Lercari, F., Carazza, T., Domenicucci, S., 2014. Epidemiology of atrial fibrillation: European perspective. Clin. Epidemiol. 6, 213.

doi:10.2147/CLEP.S47385 


\section{Figure captions}

Fig. 1. Representative current-time plot showing the steps included in the screening protocol. The first reference application (100 $\mu \mathrm{mol} / \mathrm{l}$ bicuculline) was used to normalize current inhibtion. The last saline application prior to the first application of the drug was used as baseline. Only measurements correspondoding to steady states were considered to calculate $\mathrm{IC}_{50}$.

Fig. 2. Voltage ramp protocol used to measure the $I_{\mathrm{KCa}}$ currents (top left). Representative current-voltage graph (top right) showing the measured $I_{K C a}$ current (grey line) and its inhibition by $100 \mu \mathrm{mol} / \mathrm{l}$ bicuculline (black line). Effect of amiodarone $(n=6)$, disopyramide $(n=8)$, dronedarone $(n=5)$, flecainide $(n=6)$, ibutilide $(n=5)$, quinidine $(n=5)$, sotalol $(n=5)$ and vernakalant $(n=5)$ on $\mathrm{hK}_{\mathrm{Ca}} 2.3$ (mean \pm S.E.M.). Increasing concentrations of AADs were tested on $\mathrm{hK}_{\mathrm{Ca}} 2.3$, starting from $0.1 \mu \mathrm{mol} / \mathrm{I}$ and up to $30 \mu \mathrm{mol} / \mathrm{I}$. In the case of amiodarone, the starting concentration was 0.3 $\mu \mathrm{mol} / \mathrm{l}$ and the highest concentration $100 \mu \mathrm{mol} / \mathrm{l}$.

Fig. 3. Representative current-time plots of $A$ ) dofetilide and B) propafenone inhibition on the $\mathrm{hK}_{\mathrm{Ca}} 2.3$ (left) and their current-voltage recordings (right).

Fig. 4. Inhibition curves of dofetilide and propafenone on $\mathrm{hK}_{\mathrm{Ca}} 2.2$ (grey lines) and $\mathrm{hK}_{\mathrm{Ca}} 2.3$ (black lines). None of the compounds showed any subtype selectivity. 
Table 1 list of tested AADs, current or channels/receptors blocked by the drug and their effective free therapeutic plasma concentration for AF treatment.

\begin{tabular}{|c|c|c|}
\hline Drug & $\begin{array}{l}\text { Current/channel/receptors (Waks } \\
\text { and Zimetbaum, 2016) }\end{array}$ & $\begin{array}{l}\text { Effective free therapeutic plasma } \\
\text { concentration (nmol/l) }\end{array}$ \\
\hline Amiodarone & $I_{\mathrm{Na}}, I_{\mathrm{Kr}}, I_{\mathrm{Ks}}, I_{\mathrm{Kur}}, I_{\mathrm{CaL}}, I_{\mathrm{KAch}}, I_{\mathrm{to}}, \alpha, \beta$ & 0.3 - 0.6 (Redfern et al., 2003) \\
\hline Disopyramide & $I_{K r}, I_{N a}, I_{K A c h}$ & 215 - 800 (Redfern et al., 2003) \\
\hline Dofetilide & $\mathrm{I}_{\mathrm{kr}}$ & 0.4 - 1.5 (Redfern et al., 2003) \\
\hline Dronedarone & $I_{\mathrm{Na}}, I_{\mathrm{Kr}}, I_{\mathrm{Ks}}, I_{\mathrm{K} 1}, I_{\mathrm{CaL}}, I_{\mathrm{KAch}}, \alpha, \beta$ & $150-300^{1}$ (Patel et al., 2009) \\
\hline Flecainide & $\mathrm{I}_{\mathrm{Na}}$ & $400-900$ (Redfern et al., 2003) \\
\hline Ibutilide & $\mathrm{I}_{\mathrm{Kr}}$ & 0.8 - 150 (Redfern et al., 2003) \\
\hline Propafenone & $I_{\mathrm{Na}}, \beta$ & 30 - 300 (Redfern et al., 2003) \\
\hline Quinidine & $I_{\text {Kr }}, I_{\text {Ks }}, I_{t o}, I_{\text {KATP }}, I_{\mathrm{CaL}}, I_{\text {Na }}, I_{\text {KAch }}$ & $750-3,000$ (Redfern et al., 2003) \\
\hline Sotalol & $I_{k r}, \beta$ & $2,000-15,000$ (Redfern et al., 2003) \\
\hline Vernakalant & $\mathrm{I}_{\text {Kur }}$ & 1,000 - 10,000 (Fedida, 2007) \\
\hline
\end{tabular}

${ }^{1}$ steady state plasma concentration after 7 days.

Figure 1

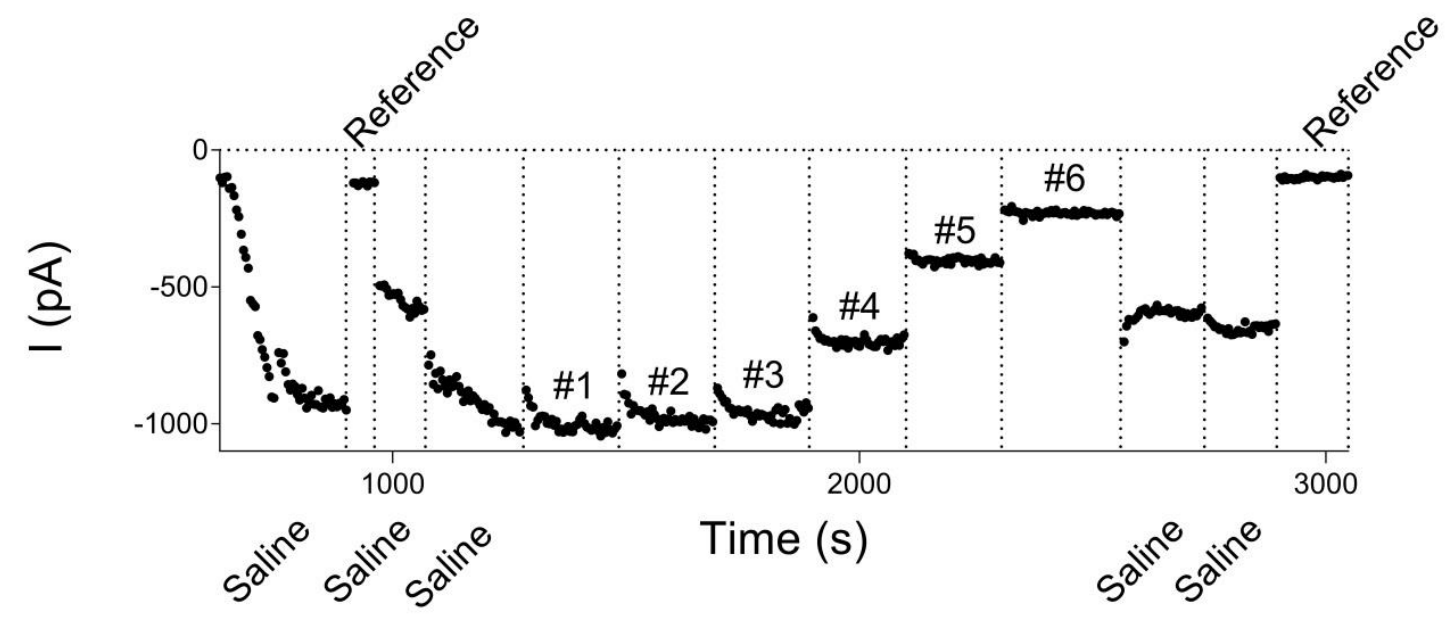


Figure 2
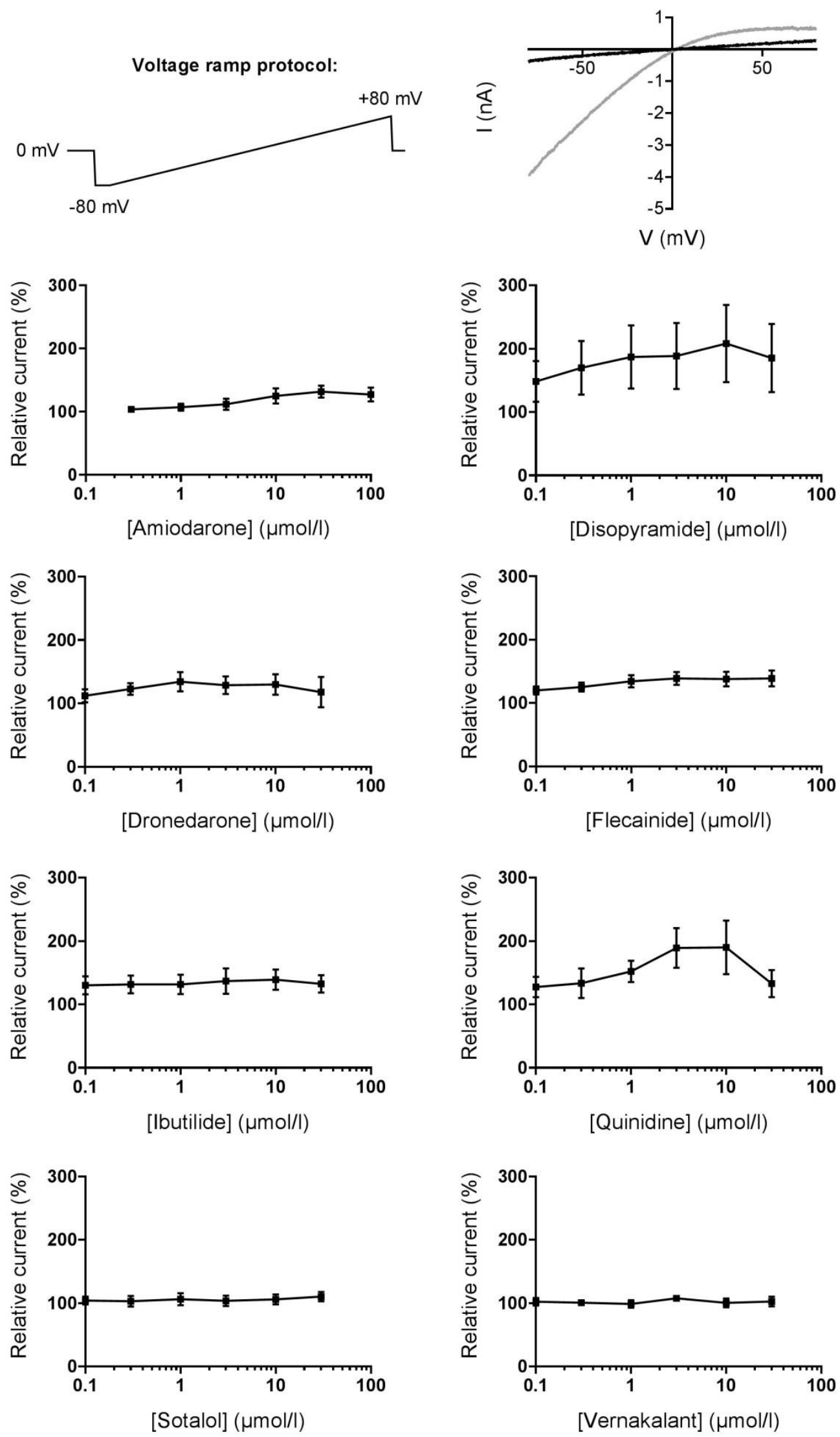
Figure 3
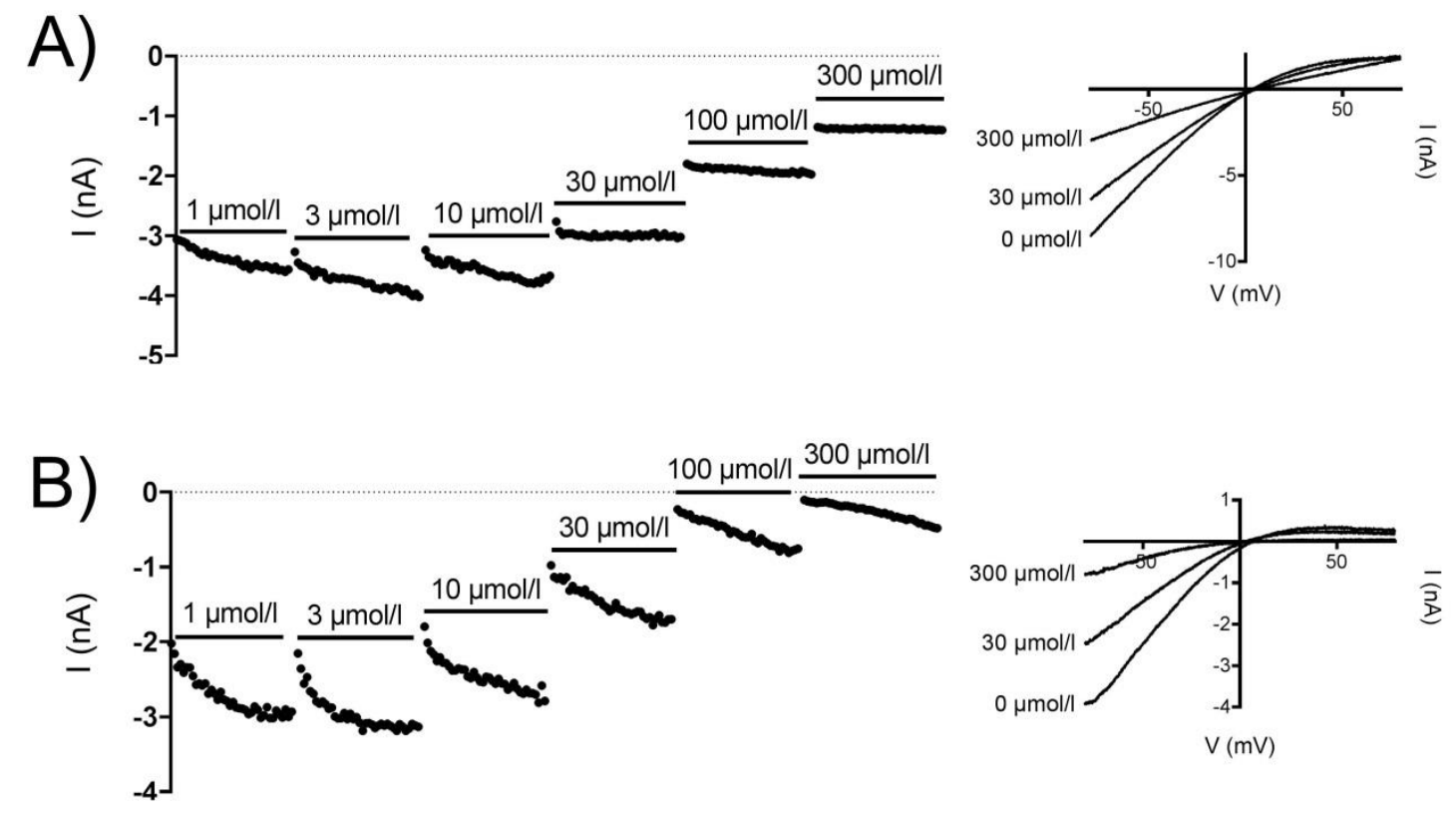

Figure 4
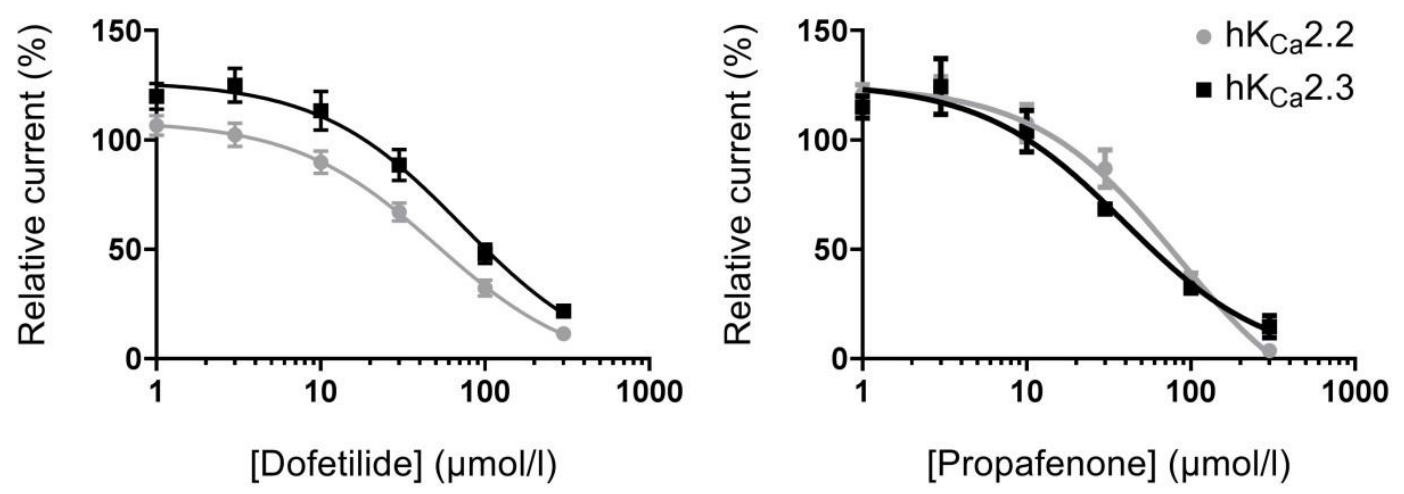